\title{
Status of Valuable Components from Pangasius: A Review
}

\author{
N.B. Rathod ${ }^{\text {* }}$, A.U. Pagarkar ${ }^{2}$, K.H. Pujari ${ }^{1}$, P.E. Shingare ${ }^{3}$, S.B. Satam², \\ G.G. Phadke ${ }^{4}$ and B.V. Gaikwad ${ }^{2}$
}

${ }^{1}$ Post Graduate Institute of Post-Harvest Management, Roha, Dist. Raigad, Dr. Balasaheb Sawant Konkan Krishi Vidyapeeth, Dapoli, India

${ }^{2}$ Marine Biological Research Station, Zadgaon, Rtanagiri-415612 (Maharashtra), India

${ }^{3}$ Taraporewala Marine Biological Research Station, Bandra, Mumbai- (Maharashtra) India

${ }^{4}$ ICAR-Mumbai Research Centre of Central Institute of Fisheries Technology, CIDCO Admin Building 1, Sector 1, Vashi, Navi Mumbai, 400 703, Maharashtra, India

*Corresponding author

\begin{tabular}{|c|c|}
\hline & A B S T R A C T \\
\hline & rowing fresh water species in aquaculture. \\
\hline Keywords & $\begin{array}{l}\text { Different research findings have revealed development of various value added products } \\
\text { from pangasius having global acceptance and commercial potential. The industry has }\end{array}$ \\
\hline $\begin{array}{l}\text { Pangasius, Value } \\
\text { addition and Waste } \\
\text { utilization }\end{array}$ & $\begin{array}{l}\text { expanded in terms of production and trade. Basa is being the preferred imported variety of } \\
\text { Pangasius. It is now traded to well over } 100 \text { countries worldwide due to its mild flavor, } \\
\text { whiter meat color and flaky cooked texture. The fish farmers practicing aquaculture have }\end{array}$ \\
\hline Article Info & $\begin{array}{l}\text { reported reduced profit margin. Also there is a great scope to increase the fish consumption } \\
\text { by developing different varieties of innovative value added ready-to-eat, ready-to-cook, }\end{array}$ \\
\hline $\begin{array}{l}\text { Accepted: } \\
16 \text { March } 2018 \\
\text { Available Online: } \\
10 \text { April } 2018\end{array}$ & $\begin{array}{l}\text { ready-to-sever 'convenience' fish products, demand for which has increased due to social } \\
\text { and cultural changes in recent years. The waste material from Pangasius fish especially } \\
\text { skin and bones on proper processing is considered as cheap source of valuable material } \\
\text { having several food applications. This paper highlights the different types of value added }\end{array}$ \\
\hline
\end{tabular}

\section{Introduction}

Pangasius is a type of catfish that is endemic to the waters of Mekong basin in south-east Asia, belongs to the family Pangasiidae. This fish species is also known as Pangasianodon hypophthalmus, Sutchi catfish, striped catfish or Tra fish (Guimarães et al., 2015). Pangasius catfish is one of world's fastest growing fresh water species in aquaculture (Jeyakumari et al., 2016). Pangasius is now traded to well over 100 countries worldwide as skinless and bone less fillets popularly along with portions, steaks, fillets and its added value products (Thi et al., 2013). The industry has expanded in terms of both production and trade.

The Pangasius attains body weight of 1.2 to $1.3 \mathrm{~kg}$ rapidly within a short span of 6 months but usually harvested after 8 months 
depending on marketability (Gurung et al., 2016). It is characterised by tender and white flesh, absence of fishy odour, firm cooked texture and high nutritive value with excellent sensory attributes has expanded consumer preference for Pangasius (Rao et al., 2013).

High market demand and soared product prices for different Pangasius species reflect consumer preferences, Basa is the preferred imported variety of Pangasius, while the farmers undertaking Pangasius culturing have reduced profit margins.

There is great scope to increase the consumption by developing different value added products from Pangasius due to a mild flavor, white flesh color, firm cooked texture, low fat content (Orban et al., 2008), easily digestible protein (Thammapat et al., 2010) and nutritional properties beneficial for human health (Usydus et al., 2011).

There is great demand for fish based products especially value added products, ready-to-eat 'convenience' products (Rathod and Pagarkar, 2013) due to recent social and cultural change. Filleting industry produces significant amounts of head, bone, scrap meat and skin by-products (Thuy et al., 2010) which on proper processing can be converted to various high value products having good economic efficiency. Fish processing waste is good potential source of gelatin and more than $30 \%$ fish weight comes from skin and bones. Also, utilization of waste as a source of potential value added products can reduce waste (Atma, 2017).

\section{Global status of pangasius}

Global aquaculture production of pangasius was 419387 tons (FAO, 2015). In Vietnam, Pangasius is mainly processed for export market, in 2008 alone export of Pangasius surpassed rice, coffee and shrimps while in
2012 export to Europe alone was around 143,200 tons. Italy annually imports approximately 12,780 tons (Dambrosio et al., 2016).

\section{Value addition}

Adding value means employing processing methods, specialized ingredients or novel packaging to enhance the nutrition, sensory characteristics, shelf life and convenience of food products.

Now-a-days, development of low cost, high energy and nutrient rich food is a constant challenge in developing countries (Pagarkar et $a l ., 2011)$. As per the changing demand of the consumer while developing new meat products or upgrading the existing following factor should be consider.

Developed from the naturally occurring raw materials.

Consumed as a part of daily life and have good acceptability.

Subjected to minimum processing or no additives or less additives.

Economical.

Should be easy to handle, preserve, store and prepare.

Minimum impact to the environment.

The fish and fish products are considered as the most healthy food component of the human diet. Therefore, demand for fish products has increased in national and international markets.

Studies on different types of value added products developed from Pangasius fish are detailed below: 


\section{Pangasius fillet}

Pangasius fillets are affordable substitute for white fleshed fishes in the western market with ever increasing acceptability and popularity, usually Pangasius is served to the European market as skinned and boneless frozen fillets (Noseda et al., 2012), currently been exported to over 100 countries worldwide (Guimarães et al., 2015), popularly known as 'Basa' (Rao et al., 2013) accordingly development of value added fillet also support the growth in production (Ramadhan et al., 2016).

Pangasius fillets are value added product made by separating meat from thorns, skins and other unwanted material which is then frozen stored. Fillets are advantageous as they are easily processed and consumed food materials as a whole. They also require very less storage space due to their flat shape, which makes them easy to stack (Ramadhan et al., 2016).Preparing and marketing value added fillets from Pangasius fish is more economical and easy(Rao et al., 2013).

Orban et al., (2008) studied the new trends in the seafood market, nutritional quality and safety aspects of frozen and thawed fillets of (P. hypophthalmus) in the Italian market. Proximate composition, mineral content, fatty acid profile, unsaponifiable components of the lipid fraction and drip loss during thawing at $5^{\circ} \mathrm{C}$ were determined on the fillets. Fillets were characterised by high moisture levels $80 \%$ and low crude protein $15.6 \%$ and lipid $3.0 \%$ contents. Total lipids were characterised by low cholesterol levels $39 \mathrm{mg} / 100 \mathrm{~g}$, high percentages of saturated fatty acids $47.8 \%$ of total fatty acid and low percentages of polyunsaturated fatty acids $18.8 \%$ of total fatty acids, which were mainly represented by linoleic acid $59 \%$ of total polyunsaturated fatty acids. The mineral composition was characterised by a high sodium content 594 $\mathrm{mg} / 100 \mathrm{~g}$, probably partially due to the sodium tripolyphosphate used to retain moisture. As regards safety aspects, the quality of the samples analysed was good, with low residue levels of mercury, organochlorine pesticides and polychlorinated biphenyls.

Domiszewski et al., (2011) assessed Pangasius fillets one year before expiration date for effect of different heat treatment on quality of lipids via gas chromatography. Results showed conventional cooking and microwave cooking had no change on saturated fatty acids (SFA) and mono unsaturated fatty acids (MUFA) while $10 \%$ change in Poly unsaturated fatty acid (PUFA) including Eicosapentaenoic acid (EPA) and Docosahexaenoic acid (DHA). EPA and DHA were reported to be $16.5,12,22,23 \mathrm{mg}$ in raw, conventional cooked, microwave cooked and frying cooked fillets. Heat treatment helped maintaining lipid quality all samples had peroxide value (PV) below 3 meq $\mathrm{O}_{2} / \mathrm{kg}$ lipids and Anisidine value below 1.5. Addition of salt during boiling increased peroxides 16 times and secondary oxidation products 4 times. Suggesting Pangasius as alternative to prok.

Noseda et al., (2012) microbial spoilage of vacuum and modified atmosphere packaged Vietnamese $P$. hypophthalmus fillets were studied. Moreover, they examined the growth and metabolite production of micro-organisms causing spoilage in air, vacuum and modified atmospheres (MAP) (MAP 1- 50\% $\mathrm{CO}_{2} ; 50 \%$ $\mathrm{N}_{2}$ and MAP 2- $50 \% \mathrm{CO}_{2} ; 50 \% \mathrm{O}_{2}$ ) of $P$. hypophthalmus fillets during storage at $4^{0} \mathrm{C}$. Their result showed that use of $\mathrm{CO}_{2}$ in modified atmosphere packaged Pangasius fillets significantly prolonged the shelf life compared to air and vacuum packaged fillets. Also found out that ethanol, 2,3-butanediol, diacetyl, acetoin, ethyl acetate, acetic acid and sulphur compounds like hydrogen sulfide, methylmercaptan, carbon disulphide and 
dimethyl disulphide were the major spoilage related compounds in packed Pangasius fillets.

Rao et al., (2013) investigated the effect of vacuum and polyphosphate on Pangasius fillets during chill storage. They concluded thatchilled stored $\left(<4{ }^{\circ} \mathrm{C}\right)$ Pangasius fillets using ice provide a minimum shelf life of 9 days. Whereas, fillets treated with $2 \%$ STPP and $1 \% \mathrm{NaCl}$ proved to be beneficial as it increased moisture retention, lowered bacterial and delayed biochemical spoilage with improved textural quality.

Recently, Guimarães et al., (2015) evaluated the chemical quality parameters regarding frozen $P$. hypophthalmusfillets from Vietnam. The authors reported presence of mercury (Hg) and malondialdehyde (MDA) hazardous compounds in more than $50 \%$ of studied samples along with detrimental compounds. Suggested the need for quality control points in production chain to promote product standardization for safer food supply chain.

Ikasari and Suryaningrum (2015) assessed the quality changes in Pangasius fillets during ice storage filleted by various methods. Findings reported methods of filleting did not significantly influence the quality during storage all samples were not acceptable after storage for 18 days.

Viji et al., (2015a) studied the effects of turmeric treatment and smoking on the shelf life of ready-to-cook fillets from Pangasius catfish during chill storage and the results showed that turmeric treatment and smoking has a positive effect in controlling the quality changes associated with storage of the readyto-cook smoked fillets.

\section{Steaks/Chunks}

Fish steak being a ready-to-cook value added product, acceptable in both domestic and international markets (Lakshman et al., 2015). Mohan et al., (2008) assessed the effectiveness of $\mathrm{O}_{2}$ scavenger on shelf life of Pangasius catfish steaks during chilled storage. Results showed that $\mathrm{O}_{2}$ scavenger reduced the oxygen content by $99.58 \%$ within $24 \mathrm{~h}$ in packages. $\mathrm{O}_{2}$ scavenger packaged steaks maintained chemical (pH, TVB-N, TMA-N, TBA and PV), physical (drip loss and water holding capacity), microbial (total mesophilic and psychrotrophic counts), sensory qualities and lipid oxidation was reduced significantly, which extended the shelf life of steaks upto 20 days in comparison to air pack which had half the life 10 days.

Viji et al., (2014) evaluated the shelf life of Pangasius steaks during iced and chilled storage accordingly sensory analysis reported that iced steak had additional shelf life of 3 more days i.e., 14 days in comparison of 17 days in ice stored, biochemical quality indices $\mathrm{pH}$, TVBN, TBA and PV were within acceptable limits in both storages throughout the period. Total mesophilic count and Enterobacter counts were lower in ice stored in comparison to chill stored, while the chill stored steaks showed higher textural deterioration on comparison with ice stored steaks.

Kumari et al., (2016) developed Pangasius steaks by sous-vide technology with its process optimization. Results suggested suitable combination of chitosan and spices which enhanced antimicrobial and oxidative stability. Chitosan concentration of $1.08 \%$, temperature of $70.93^{\circ} \mathrm{C}$ and cooking time of 16.48 min as optimised conditions for sousvide processing of Pangasius steaks

Recently, Kumar et al., (2017) analysed the suitability of Pangasius steaks for development of fermented product during its storage in PVC jar. Results confirmed development of characteristic flavour, 
firmness and taste over the period of 135 days of study. During which moisture, ash, salt and free $\alpha$-amino nitrogen (FAN) increased, thiobarbutric acid reactive substances (TBARS) showed a rising trend till 75 days and decreased continuously till maturity. Finally, fully fermented product had $56.67 \%$, $5.93,18.17 \%, 14.43 \%, 0.21 \mathrm{mg} / \mathrm{kg}$ and $92.86 \mathrm{mg} / 100 \mathrm{gm}$ of moisture, $\mathrm{pH}$, ash, salt, TBARS and FAN respectively.

Jeyakumari et al., (2017) studied the effect of spice extract (ginger, mint and green chilli) on biochemical, textural and sensory characteristics of chunks from Pangasius fish while the results suggested that $20 \%$ spice extract with ginger and mint can be used effectively as dip treatment to improve the sensory attributes, delay chemical deterioration and extend the shelf life of chunks. Sensory evaluation revealed that chunks had shelf life of 15, 12 and 9 days for treatment with ginger, mint and chilli extract during study; also concluded that chunks treated with ginger and chilli extract had improved textural properties over mint treatment (Table 1).

\section{Meat/Mince}

Pangasius fish, has become an economical valuable freshwater fishery product (Noseda et al., 2012). Consumer preferences for Pangasius have increased due to its tender flesh, absence of fishy odour along with firm texture when cooked and high nutritive value with excellent sensory properties (Rao et al., 2013) which forms the base material for development of various value added products.

Recently, due to increase in production of Pangasius species the profits has been lowered for producers. Development of different value added products from the fish with higher margin can be the considered as an alternative to increase the profit (Viji et al., 2015 a).
Viji et al., (2015 b) studied the proximate composition of fresh Sutchi catfish $(P$. hypophthalmus) meat, found that it contains $17.63 \pm 0.33 \%$ protein, which indicates that the fish can be considered as a good table fish.

Fat content was found to be $2.12 \pm 0.26 \%$ which relates to its delicious taste, whereas moisture and ash content of the fish were $77.43 \pm 1.46 \%$ and $1.07 \pm 0.12 \%$, respectively.

Hassan et al., (2016) studied the effects of cryoprotectants (4\% sucrose, and $4 \%$ sorbitol with $0.2 \%$ STPP) on Pangasius mince during refrigerated storage. Results from biochemical analysis (NPN, FFA, PV, TVBN and TBARS), proximate changes, $\mathrm{pH}$, textural, SDS PAGE and sensory analysis concluded that cryoprotectants had no effect on quality improvement on Pangasius mince and had a shelf life of 3 days during refrigerated storage.

\section{Surimi}

Surimi is the Japanese term for concentrated myofibrillar protein which is defined as mechanically de-boned, washed and cryostabilized fish paste that is used for the production of seafood analogues and other new products (Jeyakumari et al., 2016). It is frozen and stored in block form. Surimi is the raw material for gel based snack foods such as kamaboko (Desai et al., 2007; Thorat et al., 2007) and fish balls (Balange et al., 2004; Santana et al., 2012; Kolekar et al., 2013; Majumdar et al., 2016). Pangasius is cultured on large scale in India and Bangladesh having a high growth rate so, the excess catch of striped catfish can be alternatively converted to surimi and used as base for making restructured products (Majumdar et al., 2016).

Majumdar et al., (2016) investigated the effect of natural spice extracts on textural and functional properties of surimi from striped catfish Pangasius. 
Table.1 Different studies on development of products from Pangasius

\begin{tabular}{|c|c|c|}
\hline Products & Study conducted & Reference \\
\hline $\begin{array}{l}\text { Gutted } \\
\text { and whole } \\
\text { fish }\end{array}$ & $\begin{array}{l}\text { Reported the effects of gutting on shelf life of whole fish in comparison to } \\
\text { ungutted fish during ice storage. Results indicated gutting improved the } \\
\text { sensorial quality, microbial analysis determined shelf life of 16-18 days and 18- } \\
20 \text { days for gutted and ungutted fish respectively, whereas pH didn't showed } \\
\text { any significant changes in both cases, while gutted fish expressed higher rate of } \\
\text { primary lipid oxidation than ungutted fish. Total volatile base nitrogen (TVB- } \\
\mathrm{N} \text { ), alpha amino nitrogen (AAN), free fatty acids (FFA) and thiobarbituric acid } \\
\text { reactive substance (TBARS) parameters lowered in gutted ones in comparison } \\
\text { to un-gutted fish. }\end{array}$ & $\begin{array}{l}\text { Viji et al., } \\
(2015 b)\end{array}$ \\
\hline \multirow[t]{7}{*}{ Fillets } & $\begin{array}{l}\text { Studied nutritional qualities and safety aspects of Pangasius fillets produced in } \\
\text { Vietnam, available on Italian market. Fillets were characterized by high } \\
\text { moisture and low protein and lipid content. Total lipids consisted of low } \\
\text { cholesterol levels, high percentages of saturated fatty acidsand low percentages } \\
\text { of polyunsaturated fatty acids. The quality of analysed samples was good with } \\
\text { low residues of mercury, organochlorine pesticides and polychlorinated } \\
\text { biphenyls. }\end{array}$ & $\begin{array}{l}\text { Orban et al., } \\
(2008)\end{array}$ \\
\hline & $\begin{array}{l}\text { Assessed effects of different heat treatment on lipid quality of Pangasius. } \\
\text { Results showed changes in PUFA including EPA and DHA by } 10 \% \text { and no } \\
\text { change in SFA and MUFA on different heat treatments. Lipids maintained good } \\
\text { quality after the treatment - PV of every sample was below } 3 \text { meq } \mathrm{O}_{2} / \mathrm{kg} \text { lipids } \\
\text { and Anisdine Value below } 1.5 \text {. Addition of salt during boiling increased } \\
\text { peroxides 16- times and fourfold increase in the amount of secondary oxidation } \\
\text { products. }\end{array}$ & $\begin{array}{l}\text { Domiszewski et } \\
\text { al., (2011) }\end{array}$ \\
\hline & $\begin{array}{l}\text { Investigated the microbial spoilage of vacuum and MAP packaged Pangasius } \\
\text { fillets. Based on results of microbial analysis shelf life of air packed fillets, } \\
\text { vacuum, MAP1 }\left(50 \% \mathrm{CO}_{2} \& 50 \% \mathrm{~N}_{2}\right) \text { and MAP } 2\left(50 \% \mathrm{CO}_{2} \& 50 \% \mathrm{O}_{2}\right) \text { were } \\
\text { found to be } 7,10,12 \text { and } 14 \text { days respectively. }\end{array}$ & $\begin{array}{l}\text { Noseda et al., } \\
(2012)\end{array}$ \\
\hline & $\begin{array}{l}\text { Studied the shelf life of Pangasius fillet with treatment of sodium } \\
\text { tripolyphosphate (STPP)and vacuum during chilled storage, treated samples had } \\
\text { shelf life of } 9 \text { days with improved texture and better moisture retention. }\end{array}$ & Rao et al., (2013) \\
\hline & $\begin{array}{l}\text { Assessed the storability of Pangasius fillets, filleted by different methods under } \\
\text { ice storage. Concluded with no significant effect of method of filleting on shelf } \\
\text { life under ice storage all samples were unacceptable after } 18 \text { days. }\end{array}$ & $\begin{array}{l}\text { Ikasari and } \\
\text { Suryaningrum } \\
(2015)\end{array}$ \\
\hline & $\begin{array}{l}\text { Evaluated effects of turmeric treatment and smoking on Pangasius fillets during } \\
\text { chill storage. Results revealed that treatment with } 2 \% \text { turmeric and smoking at } \\
60^{\circ} \mathrm{C} \text { for } 1 \mathrm{~h} \text { and } 2 \mathrm{~h} \text { had shelf life of } 14 \text { and } 21 \text { days respectively on storage at } \\
4^{0} \mathrm{C} \text { on comparison the respective control samples had } 7 \text { and } 17 \text { days } \\
\text { respectively. }\end{array}$ & $\begin{array}{l}\text { Viji et al., } \\
(2015 \mathrm{a})\end{array}$ \\
\hline & $\begin{array}{l}\text { Studied effects of different frozen techniques on chemical and microbiological } \\
\text { qualities of Pangasius fillets. Results revealed presence of microbes but, within } \\
\text { range prescribed by International commission on microbiological specification } \\
\text { for foods (ICMSF) also the chemical (six metal indicator) quality were below } \\
\text { safety levels for human consumption. }\end{array}$ & $\begin{array}{l}\text { Dambrosio et al., } \\
\text { (2016) }\end{array}$ \\
\hline \multirow[t]{2}{*}{$\begin{array}{l}\text { Steaks/ } \\
\text { Chunks }\end{array}$} & $\begin{array}{l}\text { Assessed the scavenging effect of } \mathrm{O}_{2} \text { scavengers on shelf life of chilled stored } \\
\text { panagasius steaks. Results concluded that } \mathrm{O}_{2} \text { scavengers effectively reduced the } \\
\text { oxygen concentration by } 99.58 \% \text { in } 24 \mathrm{~h} \text { in packages, which had direct impact } \\
\text { on shelf life which was doubled in comparison to air packs ( } 10 \text { days), by } \\
\text { maintaining chemical, microbial and sensory attributes. Significant reduction in } \\
\text { lipid oxidation was noted in steaks packed with } \mathrm{O}_{2} \text { scavenger. }\end{array}$ & $\begin{array}{l}\text { Mohan et al., } \\
(2008)\end{array}$ \\
\hline & $\begin{array}{l}\text { Studied the quality changes of Pangasius steaks in iced }\left(0^{0} \mathrm{C}\right) \text { and chill }\left(4^{0} \mathrm{C}\right) \\
\text { storage. Results revealed biochemical quality parameters } \mathrm{pH} \text {, total volatile base- }\end{array}$ & al., (2014) \\
\hline
\end{tabular}




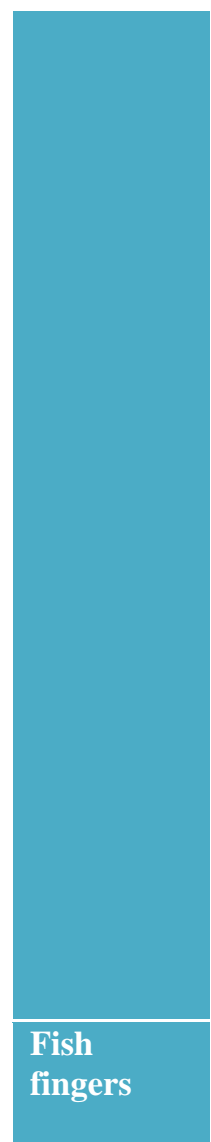

Mince

Surimi
Nitrogen (TVB-N), thiobarbituric acid (TBA) and peroxide value (PV) were in acceptable range during storages. Iced steaks showed lowered Total mesophilic and Enterobacter counts in comparison to chilled stored, on contrary the chilled stored steaks showed greater extent of deterioration in texture. Pangasius steaks stored in chilled and iced storage had shelf life of 14 and 17 days respectively based on sensory and microbiological analysis.

Developed Pangasius steaks by sous-vide with its process optimized. Results based on study suggested appropriate blend of chitosan and spices for enhanced antimicrobial and oxidative stability, while process optimization suggested $1.08 \%$ chitosan concentration, $70.93^{\circ} \mathrm{C}$ as cooking temperature and $16.48 \mathrm{~min}$ for cooking time as optimum condition.

Suitability of Pangasius as raw material for salt fermented product during 135 days was analysed in PVC jar. Analysis confirmed that ash, salt and free $\alpha$ amino nitrogen (FAN) showed a rising trend. Thiobarbituric acid reactive substance (TBRAS) content increased till $75^{\text {th }}$ day further and decreased till maturation which concluded that Pangasius developed the characteristic flavour and consistency over 135 days of maturation.

Studied antioxidant and total phenolic effects of different spice extract (ginger, mint and chilli) on Pangasius chunks during ice storage. Results indicated that mint extract had highest antioxidant and phenolic content in comparison to other two, while Pangasius fish chunks treated with $20 \%$ spice extract showed lower values of TVB-N, PV and TBA on comparison to control samples. Textural quality of chunks treated with ginger and chilli had improved over mint, sensory evaluation revealed that the samples had shelf life of 9,12 and 15 days for control (untreated), chilli, mint and ginger treated samples respectively. Studied percentage of meat yield in different stages during dressing of Pangasius fish. They prepared fish fingers from Pangasiusfish and battered with different types of battering materials.

Evaluated suitability of Pangasius mince for production of restructured fish products with use of microbial transglutaminase (MTGase) along with sodium caseinate $(1 \%)$ and egg white $(2 \%)$ as protein substrate for MTGase by hot and cold setting. Results suggested use of protein substrates (sodium caseinate and egg white) in developing MTGase mediated restructured fish products, which imparted better binding characteristics. The results also proved the pro-oxidant effect of MTGase in both settings and possibility of converting Pangasius mince to value added restructured fish products.

Studied the effects of cryo-protectants on the keeping quality of mince from Pangasius in refrigerator. Results found that Pangasius mince mixed with cryoprotectants (4\% sucrose and 4\% sorbitol with $0.2 \%$ STPP) degraded quickly under refrigerated storage which was revealed by $\mathrm{pH}$, proximate composition, biochemical, textural evaluation, SDS PAGE and sensory evaluation values. Results suggested Pangasius mince can be stored only for 3 days in refrigerator.

Analysed effect of garlic's aqueous extract (GAE) on restructured products from Pangasius surimi during refrigerated storage. Incorporation of GAE enhanced water holding capacity due to good protein network formation, while lower protein solubility suggested protein aggregation. Concentration of GAE had different effect on rate of lipid oxidation while gel strength improved by GAE incorporation. Sensory evaluation revealed restructured products with $1 \%$ GAE was most acceptable.

Studied the quality changes of restructured products from Pangasius surimi incorporated with chitosan during chilled storage. Biochemical parameters (TVB-N, PV and TBA) showed a rising trend. Based on sensory and microbial analysis the developed product had shelf life of 17 days while control had 10 days.

Developed the process to optimize the process of surmi preparation from

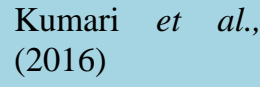

Jeyakumari et al., (2017)

Pagarkar et al., (2017)

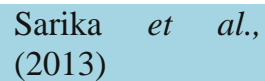

Hassan et al., (2016)

Majumdar et al., (2016)

Jeyakumari et al., (2016)

Hassan et al., 


\begin{tabular}{|c|c|c|}
\hline & $\begin{array}{l}\text { Pangasius. Results indicated that surimi obtained from third and fourth washing } \\
\text { cycles had highest gel strength, lowest expressible moisture similarly sensory } \\
\text { evaluation rated highest overall acceptability to surimi obtained with third and } \\
\text { fourth washing and concluded that three washing cycles with } 1: 3 \text { (mince: water) } \\
\text { ratio is optimum for making good quality surimi from Pangasius. }\end{array}$ & (2017) \\
\hline Pickle & $\begin{array}{l}\text { Value added product fish pickle from Pangasius fish was developed and stored } \\
\text { at ambient conditions, results showed that Pangasius pickle could be stored upto } \\
180 \text { days; during the storage tenure PV and TVB-N showed a rising trend while } \\
\text { pH showed a decreasing trend within acceptable range for } 180 \text { days. }\end{array}$ & $\begin{array}{l}\text { Patil et al., } \\
(2014)\end{array}$ \\
\hline \multirow[t]{2}{*}{ Cutlet } & $\begin{array}{l}\text { Prepared cutlet from Pangasius meat and subjected to chemical, microbial and } \\
\text { sensory analysis which showed it had shelf life of } 16 \text { days in refrigerated } \\
\text { display unit. Results found that PV, Free Fatty Acid (FFA) and TVB-N were on } \\
\text { higher side but within acceptable range, also no pathogenic organisms were } \\
\text { detected during storage period. }\end{array}$ & $\begin{array}{l}\text { Rathod et al., } \\
\text { (2013) }\end{array}$ \\
\hline & $\begin{array}{l}\text { Prepared cutlets from mince of Pangasius and studied the nutritional, texture } \\
\text { and acceptability along with effect of processing method on quality of final } \\
\text { product. Results reported that cutlets made from cooked mice were having less } \\
\text { hardness and cutting strength; while having higher protein and fat content in } \\
\text { comparison to raw mince. No significant difference was found for cutlets made } \\
\text { from raw mice, cooked mince, with or without potato, batter and breadcrumbs. }\end{array}$ & $\begin{array}{l}\text { Reddy } \\
\text { (2016) }\end{array}$ \\
\hline Patties & $\begin{array}{l}\text { Influence of mushroom (Agaricus bisporus) on quality and storability of patties } \\
\text { from Pangasius catfish. Results confirmed improvement in nutritional } \\
\text { characters by incorporation of mushrooms, also the shelf life had increased by } 4 \\
\text { days in patties treated by } 15 \% \text { button mushroom in refrigerated storage. }\end{array}$ & $\begin{array}{l}\text { Nayak et al., } \\
(2015)\end{array}$ \\
\hline Noodles & $\begin{array}{l}\text { Developed noodles by incorporating green sea weed and Pangasius fish mince, } \\
\text { results indicated use of green sea weed puree enhanced fibre content of noodles. }\end{array}$ & $\begin{array}{l}\text { Debbarma et al., } \\
(2017)\end{array}$ \\
\hline Sausages & $\begin{array}{l}\text { Sausages were prepared from fresh Pangasius minced meat and its chemical, } \\
\text { microbiological quality and textural properties were studied. The storage } \\
\text { stability of the prepared sausages at ambient and refrigerant temperature was } \\
\text { found to be } 2 \text { days and } 35 \text { days respectively. }\end{array}$ & Joshi (2012) \\
\hline \multirow[t]{4}{*}{ Gelatin } & $\begin{array}{l}\text { Extracted gelatin from Pangasius skin at } 50^{\circ} \mathrm{C} \text { for different time durations } 6,8 \text {, } \\
10 \text { and } 12 \text { hours, based on functional properties gelatin extracted at } 12 \text { hours } \\
\text { had superior qualities suggesting culinary applications. }\end{array}$ & $\begin{array}{l}\text { Ismail et al., } \\
(2013)\end{array}$ \\
\hline & $\begin{array}{l}\text { Extracted and studied the physical properties of gelatin from Pangasius fish in } \\
\text { comparison to commercial (Bovine/Porcine) gelatin. Pangasius gelatin had gel } \\
\text { strength }(513.75 \mathrm{~g}) \text {, viscosity }(3.88 \mathrm{cP}) \text {, turbidity }(73.21 \%) \text {, foaming properties } \\
\text { (foam formation ability } 1.13 \text { and foam stability } 0.71) \text {, emulsion stability ( } 34.2 \text { to } \\
44.6 \%) \text { and adhesiveness }(-369.1 \mathrm{~g} . \mathrm{sec}) \text { of the fish skin gelatin were higher on } \\
\text { comparison to bovine bone gelatin, on contrary color }\left(\mathrm{L}^{*} 43.62, \mathrm{C}^{*} 3.66 \text { and } \mathrm{h}^{\circ}\right. \\
45.28) \text {, cohesiveness }(0.838) \text {, gel elasticity, gelling and melting points of the } \\
\text { fish skin gelatin }\left(16.40^{\circ} \mathrm{C} \text { and } 26.87^{\circ} \mathrm{C} \text {, respectively) were lower than those of }\right. \\
\text { the bovine bone gelatin. }\end{array}$ & $\begin{array}{l}\text { Trakul and } \\
\text { Patcharin (2013) }\end{array}$ \\
\hline & $\begin{array}{l}\text { Optimized the process of extraction of gelatin from Pangasius skin. Results } \\
\text { suggested pre-treatment of } 0.2 \mathrm{~N} \mathrm{NaOH} \text { and } 0.1 \mathrm{~N} \text { acetic acid, with hot water } \\
\text { extraction at } 63.7^{\circ} \mathrm{C} \text { for } 2.41 \mathrm{~h} \text { which had high gel strength }(438 \mathrm{~g} \text { ) and high } \\
\text { content of amino acid (proline and hydroxyproline) }(18.01 \%) \text { with a viscosity of } \\
4.67 \mathrm{mPas} \text {. Also suggested gelatin from Pangasius also had higher quality of } \\
\text { physicochemical properties than those from bovine skin gelatin. }\end{array}$ & $\begin{array}{l}\text { Mahmoodani et } \\
\text { al., (2014b) }\end{array}$ \\
\hline & $\begin{array}{l}\text { Extracted gelatin from Pangasius skin by action of bleaching with } \mathrm{H}_{2} \mathrm{O}_{2} \\
\text { treatment. Results showed an increase in gelatin extraction from skin by action } \\
\text { of bleaching agent with improved properties. }\end{array}$ & $\begin{array}{l}\text { Sing and } \\
\text { Benjakul (2017) }\end{array}$ \\
\hline
\end{tabular}


Table.2 Proximate compositions of different products from different studies

\begin{tabular}{|c|c|c|c|c|c|c|c|c|c|}
\hline \multirow[b]{2}{*}{ Parameters } & \multicolumn{9}{|c|}{ Products } \\
\hline & $\begin{array}{l}\text { Pangasius } \\
\text { skin }\end{array}$ & $\begin{array}{l}\text { Pangasius } \\
\text { skin gelatin }\end{array}$ & $\begin{array}{l}\text { Pangasius } \\
\text { fish bone } \\
\text { gelatin }\end{array}$ & $\begin{array}{l}\text { Pangasius } \\
\text { mince }\end{array}$ & $\begin{array}{c}\text { Pangasius } \\
\text { meat }\end{array}$ & $\begin{array}{c}\text { Pangasius } \\
\text { Surimi }\end{array}$ & $\begin{array}{l}\text { Pangasius } \\
\text { fillet }\end{array}$ & $\begin{array}{l}\text { Pangasius } \\
\text { Pickle* }\end{array}$ & $\begin{array}{l}\text { Battered } \\
\text { and } \\
\text { breaded } \\
\text { Pangasius } \\
\text { cutlet }\end{array}$ \\
\hline Water & 60.86 & 7.05 & 9.2 & 74.79 & 77.43 & 75.82 & 84.82 & 60.25 & 61.22 \\
\hline Protein & 35.83 & 91.33 & 87.3 & 18.85 & 17.6 & 16.91 & 12.51 & 14.38 & 17.53 \\
\hline Ash & 0.18 & 1.38 & 2.6 & 1.36 & 1.07 & 0.95 & 0.77 & 5.45 & 12.05 \\
\hline Lipid & 2.19 & 0.23 & 0.96 & 4.34 & 2.12 & 2.76 & 1.65 & 17.16 & 5.59 \\
\hline Reference & $\begin{array}{l}\text { Trakul. } \\
\text { And } \\
\text { Patcharin } \\
(2013)\end{array}$ & $\begin{array}{l}\text { Mahamoodani } \\
\text { et al., (2014) }\end{array}$ & $\begin{array}{l}\text { Atma } \\
\text { (2017) }\end{array}$ & $\begin{array}{l}\text { Hassan. } \\
\text { et al., } \\
(2017)\end{array}$ & $\begin{array}{l}\text { Viji et } \\
\text { al., } \\
(2015 b)\end{array}$ & $\begin{array}{l}\text { Jeyakum } \\
\text { ari et al., } \\
\text { (2016) }\end{array}$ & $\begin{array}{l}\text { Guimarã } \\
\text { es } \text { et al., } \\
\text { (2015) }\end{array}$ & $\begin{array}{l}\text { Patil et } \\
\text { al., } \\
(2014)\end{array}$ & $\begin{array}{l}\text { Reddy } \\
\text { (2016) }\end{array}$ \\
\hline
\end{tabular}

*Contains $2.76 \%$ Carbohydrates.

Reported that the surimi made from Pangasius fish had a positive effect on gelling and textural properties by addition of aqueous extract of garlic, clove and cinnamon, also the water holding capacity increased with increase in concentration of extracts, whereas whiteness of gel which is an important attribute showed a reverse trend.

The effect of chitosan on shelf life of restructured fish products from Pangasius $(P$. hypophthalmus) surimi during chilled storage were studied by Jeyakumari et al., (2016). In which restructured products were prepared from Pangasius surimi by incorporation of chitosan subjected to qualities analysis under chilled storage and results from the study indicated that chitosan coating could be used as a natural ingredient to prevent lipid oxidation in surimi based food systems for the development of novel healthy fish products.

Recently, Hassan et al., (2017) studied the effect of the different washing cycles on gel strength and whiteness, For this study Pangasius mince was subjected to different washing cycles (one, two, three and four times) in the ratio of $1: 3$ of mince to water.
They concluded that third and fourth wash gave highest gel strength and whiteness to surimi as compared to other washing treatments to Pangasiusmince. The surimi yield was more in third washing as compared to fourth wash.

\section{Pickle}

High perishability of fish and fish products is a serious problem in tropical countries like India due to prevailing climatic conditions (Sahu et al., 2012). Pickiling is one of the traditional method of fish preservation in India, then too very few spiced and pickled products are prepared that to on a domestic scale (Chandrashekhar et al., 1978; Patil et al., 2014). Fish pickling in vinegar and edible oil with added salt, spices and condiments provide ready to eat highly acceptable convenience product with good self-stability at an ambient temperature (Sahu et al., 2012).

Development of value added product fish pickle from Pangasius fish and subjected to storage at ambient conditions to determine shelf life by analysing biochemical and organoleptic changes. The study found that 
based on biochemical and organoleptic evaluation the Pangasius pickle prepared using standard recipe was acceptable for 180 days. During storage the organoleptic acceptability increasing trend till 150 days, afterwards it shows declined trend, biochemical analysis ( $\mathrm{pH}, \mathrm{PV}$ and TVB-N) showed the product was in acceptable condition for 180 days at ambient conditions (Patil et al., 2014).

\section{Battered and breaded product}

Battering and breading is employed for value addition, which forms a main segment in ready meal market (Da and Nagalakshmi.2014). Battered and breaded product is convenience food valued greatly by the consumers all over the world (Pawar et al., 2012; Rathod et al., 2013). The process of coating with batter and bread crumbs increases the bulk of the product, thereby reducing the content of costly fish and thus reducing the cost product. Coating enhances the appearance, colour, texture and taste of food products and also the nutritional value of the product (Rathod et al., 2012).

Also, batter and breading develops unique flavours and textures in fried products. It provides tender and juicy interior foods and crispier crust outside (Da and Nagalakshmi. 2014). Coatings with different types of batters showed significant change in moisture retention and oil uptake with better sensory ratings (Pagarkar et al., 2012).

Rathod and Pagarkar (2013) investigated the quality changes of fish cutlet made from Pangasius fish based on evaluation of biochemical parameters ( $\mathrm{pH}, \mathrm{PV}$, FFA and TVB-N) and sensory qualities on storage in a refrigerated display unit $\left(-15\right.$ to $\left.-18^{\circ} \mathrm{C}\right)$. The results suggested that the cutlet was in acceptable condition for 16 days during storage. The rate deterioration was accelerated with the storage time. Biochemical parameters such as $\mathrm{pH}$, peroxide value, free fatty acid and total volatile baseNitrogen showed a rising trend during the period of study. Scores for sensory parameters viz., appearance, colour, taste, odour and overall acceptability showed a decreasing trend.

Nayak et al., (2015) evaluated the influence of Button mushroom (Agaricusbis porous) on storability and quality of patties made from Pangasius fish on refrigerated storage. Biochemical and sensory qualities indicated incorporation of mushroom was acceptable till 16 days with improved nutritional quality while one without were acceptable for 12 days only.

Reddy (2016) prepared cutlets in eight different combinations from minced meat of Pangasius fish also studied their nutritional composition, texture profile, acceptability and effects of processing methods on quality of cutlets were also evaluated. In this study it is concluded that nutritional composition, textural quality and sensorial acceptability of Pangasius cutlets is not affected by different processing methods used. Also based on availability of materials, final product quality and economic viability any method can be used to make cutlet with good quality and sensorial acceptability (Table 2 ).

\section{Gelatin}

Gelatin is heterogeneous mixture of high molecular weight water soluble protein derived from collagen by heat denaturation. The production of gelatin all over the world is about 140,000-160,000 tons per year. Pangasius filleting industry produces large amount of skin and bones byproduct which are potential source of gelatin, which is high quality protein (Mahmoodani et al., 2014a). Fish gelatin contains around $20 \%$ more 
proline and hydroxyproline amino acids in comparison to bovine and porcine gelatins which contribute to higher melting point and gel strength (Mahmood et al., 2016). Gelatin has a wide application in pharmaceutical, cosmetics along with food industries especially in body building foods (Atma, 2017). Gelatin from fish skin is more and more paid attention because of its special texture and "melt-in-mouth" property. Due to its characteristics of improving gelation, water binding, emulsifying, elastic and viscosity gelatin has wide applications (Atma, 2017).

Ismail et al., (2013) extracted gelatin from Pangasius skin at different extraction time and evaluated its effects on functional properties. Results showed extraction at $50^{\circ} \mathrm{C}$ for 12 hours as most effective on comparison to 6,8 and 10 hours, characterized by improved emulsifying capacity, emulsifying stability, water holding capacity, fat binding capacity, foaming capacity and foaming stability over other extraction times. Suggesting culinary applications to the quality gelatin extracted.

Trakul and Patcharin (2013) investigated optimal conditions for extraction of gelatin from Thai fish Pangasius (Pangasius bocourti Sauvage) skin. The results showed that the optimal condition for the extraction of gelatin from the skin of the Thai fish Pangasius was at $55^{\circ} \mathrm{C}$ for $1 \mathrm{~h}$ at $\mathrm{pH} 4.55$ which responded $20.22 \%$ yield, $506.55 \mathrm{~g}$ gel strength, 42.22 lightness $\left(\mathrm{L}^{*}\right), 3.56$ chroma $\left(\mathrm{C}^{*}\right)$ and $43.35^{\circ}$ hue angle $\left(\mathrm{h}^{0}\right)$.

Gelatin yield from Pangasius catfish skin was $23.61 \%(\mathrm{w} / \mathrm{w})$ which is significantly higher when compared with gelatin from other fish species such as: black tilapia $(5.4 \%)$, red tilapia $(7.8 \%)$, bigeye snapper $(4 \%)$, megrim $(7.4 \%)$, sole $(8.3 \%)$, cod $(7.2 \%)$ and hake $(6.5 \%)$. Also on comparison with bovine or porcine gelatin the gelatin extracted from
Pangasius fish possessed higher physicochemical properties (Mahamoodani et al., 2014).

Atma (2017) evaluated proximate composition of fish bone gelatin from different warm water species and stated that fishbone gelatin from Pangasius catfish has the highest protein content as compared to commercially available gelatin also, based upon ash content in different warm water fish tested Pangasius fish bone gelatin alone met the standard of that commercial gelatin for application in food.

Sing and Benjakul (2017) extracted and characterized gelatin from Pangasius skin and studied its colour improvement. Results showed maximum yield $16.18 \mathrm{~g}$ from skin bleached with $5 \% \mathrm{H}_{2} \mathrm{O}_{2}$ for 48 hours, also bleaching improved emulsifying and foaming properties of gelatin by oxidizing the gelatin molecule.

It has been well documented that Pangasius fish has wide application in development of value added product. Preference is given to Pangasius especially because of its comparatively lower price, easy to eat, easy to cook, good taste and its high nutritive value. Comprehensive studies are needed for specific applications towards industrial exploitation and sustainability of the final products. This review is based on published literature summarizing the importance of Pangasius and different value addition that can be carried out.

\section{References}

Atma, Y. (2017). Amino acid and proximate composition of fish bone gelatin from different warm-water species: A comparative study. IOP Conf. Series: Earth and Environmental Science 58: 
012008, doi: 10.1088/1755-1315/58/1/ 012008 .

Balange, A. K., Joshi, V. R. and Pagarkar, A. U. (2004). Preparation of pasteurized fish ball in curry and its storage study. Journal of Indian Fisheries Association, 30: 141-148.

Chandrashekhar, T. C., Rudrasetty, T. M., Lakshman P. T., Reddy and Aswathnarayana, C. (1978). Utilization of Trash Fish for Human consumption: III Studies on the development of Fish pickle from Nemipterus japonicas. Fish. Technol. (1978) 15:125-128.

Da, O., and Nagalakshmi, K. (2014). Breaded and Battered Seafood Products: Principles and Processing Methods. Beverage \& food world. Vol. 41 - No. 10, 26-29.

Dambrosio, A., Normanno, G., storelli, A., Barone, G., Ioanna, F., Errico, L., Centoducati, G. and Storelli, M. M. (2016). Aspects of Vietnamese sutchi catfish (Pangasius hypophthalmus) frozen fillet quality: microbiological profile and chemical residues. Journal of food safety, 36(4), 532-536.

Debbarma, J., Viji, P., Rao, B. M. and Prasad, M. M. (2017). Nutritional and Physical characteristics of noodles incorporated with green sea weed (Ulva reticulata) and fish (Pangasianodon hypophthalmus) mince. Indian J. Fish., 64(2): 90-95, 2017.

Desai, A. S., Joshi, V.R. and Pagarkar, A. U. (2007). Effect of modified starch on the shelf life of frozen fish ball in curry at $20{ }^{\circ}$ C. Asian J. of Microbiol., Biotech. andEnvi. Sci., 9 (1): 107-112.

Domiszewski, Z., Bienkiewicz, G., \&Plust, D. (2011). Effects of different heat treatments on lipid quality of striped catfish (Pangasius hypophthalmus). Acta Scientiarum Polonorum Technologia Alimentaria, 10(3), 359373.
FAO fisheries and aquaculture statistics. (2015). Yearbook.

Guimarães, C. F. M., Mársico E. T., Monteiro M. L. G., Lemos, M., Mano, S. B. and Junior, C. A. C. (2015). The chemical quality of frozen Vietnamese Pangasius hypophthalmus fillets. Food Sci. \& Nutri. Published by Wiley Periodicals, Inc. Pp. 1-11.

Gurung, S., Shrestha, S. and Karki, J. (2016). Value chain of Pangasius (Pangasius hypopthalmus) in Rupandehi and Nawalparasi districts of Nepal. Int. J. Life. Sci. Scienti. Res., 2016; 2(6): 712728.

Hassan, M. A., Balange, A. K., Senapati, S. R. and Martin K. A. (2017). Effect of Different Washing Cycles on the Quality of Pangasius hypophthalmus Surimi. Fishery Technol.54: 51 - 59.

Hassan, M. A., Singh, B. C., Martin, K. A. and Balange, A. K. (2016). Effect of cryo-protectants on the quality of Pangasius hypophthalmus mince during refrigeration storage. J. Env. Bio-Sci., 30 (2):283-288.

Ikasari, D., \& Suryaningrum, T. D. (2015). Quality Changes of Pangasius Fillets During Ice Storage. Squalen Bulletin of Marine and Fisheries Postharvest and Biotechnology, 10(3), 109-120.

Ismail, N., Shukor, N., and Samicho, Z. (2013). Effects of extraction time on the functional properties of silver catfish (Pangasius sutchi) skin gelatin. Scientific Research Journal, 10(1), 6581.

Jeyakumari, A., Roy, R. George. N. and Renuka. V. (2017). Effect of Spice Extracts on the Biochemical, Textural and Sensory Attributes of Pangasius (Pangasianodon hypophthalmus) Chunks during Ice Storage. The Indian Journal of Nutrition and Dietetics, 54 (2):149-160. 
Jeyakumari. A., George. Ninan., Joshy. C. G., Parvathy. U., Zynudheen. A. A. and Lalitha. K. V. (2016). Effect of chitosan on shelf life of restructured fish products from Pangasius (Pangasianodon hypophthalmus) surimi during chilled storage. $J$ Food $S c i$ Technol. 53(4):2099-2107.

Joshi, S. (2012) Properties of proteins from Pangasius hypophthalmus and its suitability for fish sausage preparation, M.F.Sc. thesis submitted to Karnataka Veterinary, Animal and Fisheries Sciences University, Bidar, Karnataka, $106 \mathrm{pp}$.

Kolekar, A. D. and Pagarkar, A. U. (2013). Quality evaluation of ready-to-eat fish ball in curry. SAARC J. Agri., 11(1): 3543.

Kumar G. P., Balange, A. K., Martin, K. A., Nayak, B. B. and Kumar H. S. (2017). Biochemical Changes during Salt Fermentation of Pangasius hypophthalmus (Sauvage, 1878). Fishery Technol., 54: 60-65.

Kumari, N., Singh, C. B., Kumar, R., Xavier, K. M., Lekshmi, M., Venkateshwarlu, G. and Balange, A. K. (2016). Development of Pangasius steaks by improved sous-vide technology and its process optimization. Journal of food science and technology, 53(11), 40074013.

Lakshman, M., Reddy, D. A., Khuntia, B.K., Udgata, S.K. and Rath, R. K. (2015). Qualitative and quantitative changes of fried fish steaks and fish steak curry of catla (Catlacatla) during frozen storage. Int. Food Res. J., 22(5): 2057-2067 (2015).

Mahamoodani, F., Venus, A. S., Fern, S. S., Yusop, M.S. and Babji, S. A. (2014b). Optimization of Extraction and Physicochemical Properties of Gelatin from Pangasius Catfish (Pangasius sutchi) Skin. Sains Malaysiana 43(7): 995-1002.

Mahmood, K., Muhammad, L., fazilah, A., Razak, H. K. and Sulaiman, S. (2016). Review of Fish Gelatin Extraction, Properties and Packaging Applications. Food Sci. and Quality Manag. 56: 2224-6088.

Mahmoodani, F., Ghassem, M., Babji, A. S., Yusop, S. M. and Khosrokhavar, R. (2014a). ACE inhibitory activity of pangasius catfish (Pangasius sutchi) skin and bone gelatin hydrolysate. Journal of food science and technology, 51(9), 1847-1856.

Majumdar, R. K., Saha, A., Mauraya, P. K., Roy, D., Shitole, S, and Balange A, K. (2016). Textural and functional properties of surimi from striped catfish Pangasianodon hypophthalmus (Sauvage, 1878) as affected by natural spice extracts. Indian J. Fish., 63(3): 88-93, 2016.

Mohan, C. O., Chandragiri, N. R.and Teralandur, K. S. (2008). Effect of $\mathrm{O}_{2}$ scavenger on the shelf-life of catfish (Pangasius sutchi) steaks during chilled storage. J. Sci. Food Agric. 88:442-448.

MPEDA (2010). Annual Report 2009-10. Marine Products Export Development Authority, Kochi, 76 pp.

Nayak, P. C., Raju, C. V., Lakshmisha, I. P., Singh, R. R. and Sofi, F. R. (2015). Influence of button mushroom (Agaricusbi sporus) on quality and refrigerated storage stability of patties prepared from sutchi catfish (Pangasius hypophthalmus). Journal of food science and technology, 52(6), 35293538.

Noseda, B., Islam, M. T., Eriksson, M., Heyndrickx, M., Reu, K. D., Langenhove, H. V. and Devlieghere, F. (2012). Microbiological spoilage of vaccum and modified atmosphere packaged Vietnames Pangasisu 
hypophthalmus fillets. Food Microbiol., $30: 408-419$.

Orban, E., Nevigato, T., Di Lena, G., Masci, M., Casini, I., Gambelli, L., and Caproni, R. (2008). New trends in the seafood market. Sutchi catfish (Pangasius hypophthalmus) fillets from Vietnam: nutritional quality and safety aspects. Food Chemistry 110(2): 383389.

Pagarkar, A. U., Joshi, V.R., Baug, T. and Kedar, J. (2011) Value addition is need of Seafood Industries, Journal of FISHCOOPS, 23 (4), 8-14.

Pagarkar, A. U., Rathod, N. B., Baug, T. E., Pawar, P. P. and Desai, A. S. (2012). Standardisation of batter used for preparation of Pangasius (Pangasianodon hypopthalmus) cutlet. Asian j. of Microbial. Biotech. Env. Sc. 14, (4): 2012: 493-496.

Pagarkar, A. U., Satam, S. B., Naik, S. D., Shinde, K. M., Chogale, N. D., Metar, S. Y. and Dhaker, H. S. (2017) Effect of different batters on oil absorption in Pangassius, Pangasianodon hypopthalmus (Sauvage, 1878) fish fingers., Report of Research of Research Review Committee, Faculty of Fisheries, Dr. B. S. Konkan Krishi VIdyapeeth, Dapoli, Ratnagiri, 2017 : 127-130.

Patil, S. S., Pagarkar, A.U., Chaudhary, K. J., Desai, A. S. and Shaikh S. M. (2014). Organoleptic and Biochemical Quality Changes in Fish Pickle Prepared from Freshwater Catfish Pangasius (Pangasianodon hypophthalmus) Indian Vet. J., 91 (07): 12 - 14.

Pawar, P. P., Pagarkar, A. U., Rathod, N.B., Baug, T.E. and Rather, M. A. (2012). Standardisation of Recipe for Fish Cutlet Product from fresh water fish Catla (Catla catla). European Journal of Experimental Biology, 2 (6):20432048.
Ramadhan, A., Suwandi, R. and Trilaksani, W. (2016). Competitiveness strategies of Indonesia Pangasius Fillet. Indonesian Journal of Business and Entrepreneurship, 2(2), 82-92.

Rao, B. M., Murthy, N. L. and Prasad, M. M. (2013). Shelf life of chill stored Pangasius (Pangasianodon hypophthalmus) fish fillets: effect of vacuum and polyphosphate. Indian $J$. Fish., 60(4): 93-98, 2013.

Rathod, N. and Pagarkar, A. (2013). Biochemical and sensory quality changes of fish cutlets, made from Pangasius fish (Pangasianodon hypophthalmus), during storage in refrigerated display unit at -15 to -18 ${ }^{\circ}$ C. Int. J. of Food, Agri. and Veterinary Sci., 3 (1) 1-8.

Rathod, N. B., Pagarkar, A.U., Pujari, K. H., Gokhale, N. B. and Joshi, V.R. (2012). Standardisation of recipe for fish cutlet product from Pangasianodon hypophthalmus. Ecol. Env. and Cons., 18 (4): 981-986.

Reddy, V. K. (2016). Effects of formulation and processing methods on the quality and acceptability of cutlets made from minced meat of Pangas (Pangasius Pangasius). SAARC J. Agri., 14(1): 2536.

Sahu, B. B., Kumar, K., Sahu, A. K., Kumar, R., Mohanty, U. L., Maji, U. J., Noor Jahan, Sahoo, M., Samal, R. and Jayasankar, P. (2012). Quality and storage stability of low acid Murrel (Channa striatus) fish pickle at room temperature. International Food Research Journal 19(4): 1629-1632.

Santana, P., Huda, N. and Yang, T. A. (2012). Technology for production of surimi powder and potential of applications. Int. Food Res. J. 19(4): 1313-1323.

Sarika, K., Manjusha, L., Mithlesh, C., K., Nagalakshmi, K. and Venkateshwarlu, Gudipati. (2013). Textural quality and 
oxidative stability of restructured Pangasius mince: effect of protein substrates mediated by transglutaminase. J Food Science ànd Technology, 52(1), 351-358.

Singh, P., and Benjakul, S. (2017). Extraction and characterisation of gelatin from the skin of striped catfish (Pangasian odon hypophthalmus) and studies on its colour improvement. African Journal of Biotechnology, 16(1), 1-9.

Thammapat, P., Raviyan, P., and Siriamornpun, S. (2010). Proximate and fatty acids composition of the muscles and viscera of Asian catfish (Pangasius bocourti). Food Chemistry, 122(1), 223227.

Thi, A. N. T., Noseda, B., Samapundo, S., Nguyen, B. L., Broekaert, K., Rasschaert, G., and Devlieghere, F. (2013). Microbial ecology of Vietnamese Tra fish (Pangasius hypophthalmus) fillets during processing. International journal of food microbiology, 167(2), 144-152.

Thorat, A. D., Joshi, V. R., Pagarkar, A. U. and Balange, A. K. (2007). Microwave pasteursation of fish product- kamaboko with beetroot and spinach. Ecol. Env. and Cons., 13 (1): 113-118.

Thuy, N. T., Lindberg, J. E., and Ogle, B. (2010). Digestibility and Nitrogen balance of diets that include marine fish meal, catfish (Pangasius hypophthalmus) by-product meal and silage, and processing waste water in growing pigs. Asian-Australasian Journal of Animal Sciences, 23(7), 924930.

Trakul, P. and Patcharin, R. (2013). Physical properties of gelatin extracted from skin of Thai panga fish (Pangasius bocourti Sauvage). Food and Applied Bioscience Journal, 2013, 1(3): 131-145.

Usydus, Z., Szlinder-Richert, J., Adamczyk, M., and Szatkowska, U. (2011). Marine and farmed fish in the Polish market: Comparison of the nutritional value. Food Chemistry, 126(1), 78-84.

Viji, P., Somrajan T., George, N., Lalitha, K. V., Zynudheen, A. A. and Binsi, P. K. (2015 a). Effects of Turmeric treatment and smoking duration on the shelf life of ready-to-cook fillets from sutchi catfish during chill storage. J. of Food Process Engg., 1-12, doi: 10.1111/ jfpe. 12238.

Viji, P., Tanuja, S., George, N., Zynudheen, A. A. and Lalitha, K. V. (2014). Quality characteristics and shelf life of Sutchi Cat Fish (Pangasianodon hypophthalmus) steaks during refrigerated storage. Int. J. of Agri. and Food Sci. Tech., 5 (2): 105-116.

Viji., P., Tanuja., S., Ninan, G., Lalitha,K. V., Zynudheen, A. A., Binsi., P. K., Srinivasagopal. T. K. $(2015$ b). Biochemical, textural, microbiological and sensory attributes of gutted and unguttedsutchi catfish (Pangasianodon hypophthalmus) stored in ice. J Food Sci. Technol. 52(6):3312-3321.

\section{How to cite this article:}

Rathod, N.B., A.U. Pagarkar, K.H. Pujari, P.E. Shingare, S.B. Satam, G.G. Phadke and Gaikwad, B.V. 2018. Status of Valuable Components from Pangasius: A Review. Int.J.Curr.Microbiol.App.Sci. 7(04): 2106-2120. doi: https://doi.org/10.20546/ijcmas.2018.704.241 